\title{
Bankruptcy prediction models as a source of assessment of the company's financial situation
}

\author{
Justyna Beata BARLIK
}

WSB University in Wroclaw, Poland

\begin{abstract}
:
Aim: The aim of the work is to make an attempt at matching an appropriate discriminatory model to companies in the Polish energy sector in 2013-2015.

Design/Research methods: The unitary financial statements of five companies from the energy sector in Poland over the period of 2013-2015 were studied. Following the example of practical calculations, the effects and result of the methods used were presented.
\end{abstract}

Conclusions / findings: Assigning accurately a particular model to the whole energy industry is not possible, as there has not been any research so far that would allow for matching bankruptcy prediction models to specific industries and enterprises. When assessing the risk of failure, taking into account just one model is not sufficient.

Originality / value of the article: Demonstration of many methodical problems that require further research in order to find optimal methods for matching discriminatory models to specific market segments.

Key words: discriminatory models, bankruptcy of the company, financial situation.

JEL: G01,G11,G17

\section{Introduction}

In economy a company going bankrupt is a natural phenomenon playing the role of economic selection (Hadasik 1998).

In the past bankruptcy used to have local implications; however, owing to the globalization process, a company going bankrupt is nowadays increasingly more frequently associated with a so-called domino effect. The consequence of the domino

Correspondence address: Justyna Beata Barlik, WSB University in Wrocław, ul. Fabryczna 29-31, Wrocław, Poland. E-mail: DressCar@op.pl.

Received: 06-11-2017, Revised: 16-01-2018, Revised: 29-01-2018, Accepted: 16-02-2018 doi: http://dx.doi.org/10.29015/cerem.479 
effect is that the failure of one company may have broader implications affecting considerably the entire economy. Even corporate giants may go bankrupt and they are usually not prepared for this situation.

One of the important elements of the theory of bankruptcy is the strand of research focusing on quantitative models for predicting bankruptcy. Given the shortcomings of the traditional indicator-based analysis, one searched for a synthetic measure allowing for assessing a company with the highest possible accuracy. Discriminatory models have become very popular. According to experts, they represent a highly effective method of a synthetic assessment of the company's financial situation (Siemińska 2003: 124-126).

The aim of this paper is to present selected Polish discriminatory models used for assessing whether or not a company is at risk of failure, and to demonstrate their application as exemplified by selected companies over the period of 2013-2015. The research was conducted on the basis of unitary financial statements. In her research the author chose from the models available on the Polish market those which had been created by their authors also on the basis of industry.

\section{The concept of financial situation}

The concept of financial situation has been presented in publications concerned with finances, the company management, economic and financial analysis and within banking. The vast majority of authors involved in this issue sees the concept of financial situation as being the same as that of financial condition (Pierścionek 1996: 156).

In looking for an adequate definition, it is worth citing the theory advanced by the European Union Commission. It considers a firm to be in financial distress "when it is unable, whether through its own resources or with the funds it is able to obtain from its owners/shareholders or creditors, to stem losses which without outside intervention by the public authorities will almost certainly condemn it to going out of business in the short or medium term" (OJ EU 244 of 1 October, 2004). Moreover, Bień's position in this respect is worth considering as he uses the term financial situation interchangeably 
with the term of financial standing, with the latter being conceived of as the firm's competitive position on the market, its credibility and economic strength (Bien 1999: 81). E. Siemińska $(2002,2003)$ sees this concept in the same context asserting that financial situation implies the firm's position resulting from the decisions it makes and opportunities of further growth which are the outcome of those decisions.

The concept of financial condition refers to the company's sustainability, security and financial credibility, as well as the ability to generate profit or increase its value. "The condition of health" of a company is described in particular by such parameters as financial liquidity, solvency, profitability of resources and profitability of the company's operations. One can speak about a poor condition when, for example, the company lost its liquidity, fails to yield profit and it is no longer viable (www.nbportal.pl/slownik/pozycje-slownika/kondycjafinansowa). The advantage of this definition is linked to the elements it contains used for the purpose of assessing the entity's financial situation, i.e. profitability, effective management of its wealth and assets, and liquidity.

\section{A statistical discriminant analysis as an early-warning tool}

The attempts to transpose the models applied in other countries onto the Polish setting failed to bring satisfactory results. Moreover, what they brought to light was that it was necessary to create models adapted to the country's specific features. This goal became the focus of the research started in 1997 at the Institute of Economic Sciences of the Polish Academy of Sciences (PAN) (the research was headed by E. Mączyńska (Maczyńska, Zawadzki 2006) within the framework of the project Systems of early warning against business bankruptcy. Early-warning indicators funded by KBN - the State Committee for Scientific Research), with the research still going on. The global practice has confirmed that the demand for early-warning models increases drastically during a time of rapid economic and social changes, which Poland is currently experiencing. This is linked to the EU integration that is now unfolding and to the civilisational breakthrough which the world is witnessing. The competition, which has been growing as the result of those developments, is not an easy challenge 
for companies. The large scale of the changes has the effect that the uncertainties and risks involved in the functioning of companies are increasing. That is why it is so critical to have tools enabling one to receive an early warning against approaching threats. Among various early-warning tools and techniques, the application of statistical discriminant analysis has so far been the most wide-spread practice.

Discriminant analysis is a statistical method employed in solving classification problems for sets which vary in their characteristics. Discriminant variables discriminate clearly a population of objects. As a measure discriminating between the populations of objects one considers the measure expressing the ratios of the size of differences between groups to the size of differences within a group. The value of a discriminant function is made up of the sum of products of variables and the parameters of the function statistically determined, that is, the weights of those indicators. The value of the function, which is determined on the basis of classification characteristics, provides the answer, by being compared to the limit value, to which group the object in question belongs (Walczak 2007). Today, for estimating parameters of discriminant models, methods are used whose underlying approach is that of a greater acceptance of the failure to meet the requirement of a normal distribution of variables. These methods were outlined in detail in Polish literature in D. Hadasik's works (Hadasik 1998: 153).

As the analysis of the existing achievements within the scope of discriminatory models shows, the key issue in their construction is the choice and selection of indicators characterizing the condition of a company and the estimation of the weights of those indicators. The weights reflect specific features of the conditions in which a company and its environment operate.

The analysis of international and domestic works concerned with failure prediction models indicates their basic characteristics as follows:

a) Using usually a dozen or so variables illustrating basic traits of business fianancial condition, mainly, liquidity, debt and profitability. The basis here is formed predominantly by quantitative variables, with qualitative variables being used only occasionally.

b) Sporadic use of variables coming from the capital market.

c) Indicators which are characterised by normal distribution represent a vast 
majority among indicators employed in discriminatory models. The measures which are typically used in a financial analysis are not employed, i.e. profitability indicator (ratio of financial result to equity). It is on account of the problem of the dicontinuity of indicator values; a situation when the level of equity is equal to zero (Rogowski 1999: 57-58).

In her paper, the author presented Mączyńska's model, the Poznan model and the model devised by Gajdka and Stos (1996). They are the most popular models developed by Polish scientists.

Mączyńska's model was built to reflect the need of customizing Altman's model to Polish conditions. E. Mączyńska and E. Zawadzki developed 7 early-warning models. The authors carried out an analysis on a balanced sample, that is one comprising $50 \%$ of firms at risk of failure and $50 \%$ of "healthy firms. The study included 80 companies listed on the WSE in Warsaw, using financial statements from the years 1997-2001, and financial indicators calculated on their basis. The study used 45 indicators characteristic for profitability, liquidity, debt level, operational efficiency and the companies' growth dynamics. The final version of the model is given by the following formula (Mączyńska, Zawadzki 2006: 7):

$$
\begin{aligned}
& Z_{M}=1,5 w_{1}+0,08 w_{2}+10 w_{3}+5 w_{4}+0,3 w_{5}+0,1 w_{6} \\
& \text { where: } \\
& w_{1}=\frac{\text { gross profit }+ \text { depreciation }}{\text { total liabilities }} \\
& w_{2}=\frac{\text { balance sheet total }}{\text { total liabilities }} \\
& w_{3}=\frac{\text { gross profit }}{\text { balance sheet total }} \\
& w_{4}=\frac{\text { gross profit }}{\text { sales revenues }} \\
& w_{5}=\frac{\text { value of } \text { stocks }}{\text { sales revenues }} \\
& w_{6}=\frac{\text { sales revenues }}{\text { balance sheet total }}
\end{aligned}
$$


The interpretation of the results of the discriminant function for this model is as follows:

- negative value of indicator $\mathrm{Z}$ indicates a company at risk of bankruptcy,

- positive value, yet less than 1 , indicates a weak company, but not at risk of going bankrupt,

- positive value within the range of 1-2, a rather sound company,

- value above 2, a company in a very good financial condition

Another model of early warning against company's failure was developed by M. Hamrol, B. Czajka and M. Piechocki on the basis of financial statements of 100 Polish commercial companies between 1999 and 2002 (half of the companies was represented by healthy enterprises). The companies regarded as bankrupt where those for which bankruptcy procedure or arrangement procedure had already been completed. The selection of healthy companies was based on the comparable amount of assets (Kisielińska, Waszkowski 2010:24). The Poznań model is given by the following formula (www.analizy-prognozy.pl):

$$
\begin{aligned}
& Z_{p}=3,652 w_{1}+1,588 w_{2}+4,288 w_{3}+6,719 w_{4}-2,368 \\
& \text { where: } \\
& w_{1}=\frac{\text { net profit }}{\text { total capital }} \\
& w_{2}=\frac{\text { circulating capital }- \text { stocks }}{\text { short }- \text { term liabilities }} \\
& w_{3}=\frac{\text { constant capital }}{\text { total capital }} \\
& w_{4}=\frac{\text { net sales profit }}{\text { sales revenues }}
\end{aligned}
$$

The interpretation of the model: $\mathrm{Zp}<0$ a difficult financial situation $\mathrm{Zp}>0$ a good financial standing of the entity. 
Another model used in the paper is one developed by J. Gajdka and D. Stos. The studies were carried out on 40 companies listed on the Stock Exchange in the following industries: manufacture, construction and trade. In this model, discriminant function has the following form (Gajdka, Stos 1996: 59-63):

$$
\begin{gathered}
Z_{G S}=0,7732059-0,0856425 w_{1}+0,000774 w_{2}+0,9220985 w_{3} \\
+0,6535995 w_{4}-0,594687 w_{5}
\end{gathered}
$$

where:

$$
\begin{aligned}
w_{1} & =\frac{\text { sales revenues }}{\text { average value of assets } \text { in total }} \\
w_{2} & =\frac{\text { averge value of } \text { short }- \text { term liabilities }}{\text { production costs of goods sold }} \times 360 \\
w_{3} & =\frac{\text { net profit }}{\text { average value of total assets }} \\
w_{4} & =\frac{\text { gross profit }}{\text { sales revenues }} \\
w_{5} & =\frac{\text { total liabilities }}{\text { total assets }}
\end{aligned}
$$

The interpretation of the model:

$$
\begin{aligned}
& Z_{G S}>0,45 \text { company is not at risk of failure } \\
& Z_{G S}<0,45 \text { company at risk of failure }
\end{aligned}
$$

For an average user, discriminative methods are more transparent and communicative when set beside newer generation methods, such as neural networks, with their results being easier to compare and interpret.

\section{Description of energy sector in Poland}

The work that had been conducted since the beginning of the 1990s relating to the energy sector brought about the adoption of Energy Law by the Sejm of the Republic of Poland on April 101997 (Journal of Laws, No. 54, item 348), which has been in 
force (as amended) since then. This act represents the highest level of legal regulations in force for this sector. The Energy Law governs economic activity pursued within the area of energy products, with the exception of coal, which is subject to the provisions set forth in the Act of 4 February 1994 - Geological and Mining Law (Journal of Laws No. 27, item 96). The Energy Law is followed directly by executive acts to this Law issued by the Council of Ministers, Prime Minister and the Minister of Economic Affairs. There are also individual legal regulations issued by the President for the Office of Energy Regulation (URE).

Presently Polish electricity sector consists of four large capital groups which are under the state control, a few private power plants and energy distributors. As the result of the government "Program for Electricity," which intended to create four large undertakings capable of competing against other European undertakings on the free energy market, the following entities were founded: PGE Polska Grupa Energetyczna S.A. TAURON Polska Energia S.A. (former Energetyka Południe S.A.), ENEA S.A., ENERGA S.A.

PGE is the largest energy undertaking in Poland and one of the largest in Central and Eastern Europe. It is engaged in brown coal mining, the production of electricity and heat, electricity distribution and the production of energy in renewable sources. The PGE Group was established as the result of the merger of the companies BOT group and Zespół Elektrowni Dolna Odra, and on the basis of the assets left after carving out distribution companies such as ŁZE, Łódź Teren, ZEORK, ZE Białystok, ZE Warszawa-Teren, LUBZEL, ZKE and Rzeszowski Zakład Energetyczny from PSE S.A. The main shareholder of the PGE Group is the State which owns 57.39\% of the Group's shares.

Tauron Polska Energia was founded as a result of the merger of the following entities: PKE, EnergiaPro and Enion distributors, and Stalowa Wola Power Plant, Tychy Heat and Power Plant, and Przedsiębiorstwo Energetyki Cieplnej of Katowice. The group is made up of 90 undertakings linked by capital, including 17 subsidiaries. The parent company of the group is TAURON Polska Energia S.A. The state owns $30.06 \%$ of shares of the TAURON Group.

ENEA S.A. Group was established as a result of the merger of ENEA and Kozienice Power Plant. The Group's major activity is the production, distribution and 
sale of electricity. The state is the group's largest shareholder holding $51,50 \%$ of shares.

ENERGA Group was founded following the merger of ENERGA with Ostrołęka Power Plant. The Group runs its operations in the field of electricity production, trade and distribution. With $51.52 \%$ of shares, the state is its main shareholder.

The past years have seen the ever more frequent emergence of capital groups in the Polish energy sector. Considering the fact that small energy undertakings are not capable of financing their development on their own, what is necessary is continuous consolidation of the Polish energy sector. The transformations in the domestic power industry started in the early 1990s. Their objective was to adjust the sector to the conditions prevalent on the global markets. The consolidation of the Polish energy sector continues to be necessary given the fact of growing competition following Poland's accession to the EU. It is necessary for Polish energy undertakings to increase their competitiveness, and without consolidation the achievement of synergies and economies of scale is not possible. On the other hand, despite the measures undertaken to this end, the condition of the Polish energy sector may still be too weak to face these challenges.

\section{Application of discriminatory models on selected examples}

The study encompassed five undertakings from the energy sector: Tauron Polska Energia S.A., PGE S.A., Enea S.A., IDEON S.A. and Heat and Power Plant Będzin S.A over the period of 2013-2015. The selection of the companies was necessitated by having to use economic and financial data in the analysis which were available for the companies discussed to the extent allowing for conducting the analyses. The companies under study were chosen purposefully so as to allow for comparing the companies owned predominantly be the state (PGE S.A., Tauron Polska Energia S.A., Enea S.A.) with those in which the state held no shares (IDEON S.A., EC Będzin S.A.). The economic entities examined are joint stock companies listed on the Stock Exchange. For the assessment of their financial situation, the following models were used: Mączyńska's, Gajdka and Stos and the Poznań model. 
Tables 1-5 present the values obtained on the basis of the models in question. The values which demonstrate a good financial condition are in green color, while red color denotes those values of indicators which imply the risk of failure.

In 2015 Spółka Tauron Polska Energia S.A was assessed as being in a poor financial condition according to Mączyńska's model, and the model by Gajdka and Stos. The values calculated for the other years showed the company as being in a good financial condition.

Table 1. The values of indicators in the selected models for the company Tauron Polska Energia S.A. (2013-2015)

\begin{tabular}{|c|c|c|c|}
\hline MĄCZYŃSKA'S MODEL \\
\hline indicators & $\mathbf{2 0 1 3}$ & $\mathbf{2 0 1 4}$ & $\mathbf{2 0 1 5}$ \\
\hline $\mathrm{W}_{1}$ & 0.20 & 0.12 & -0.35 \\
\hline $\mathrm{W}_{2}$ & 3.28 & 3.00 & 2.68 \\
\hline $\mathrm{W}_{3}$ & 0.06 & 0.04 & -0.13 \\
\hline $\mathrm{W}_{4}$ & 0.15 & 0.13 & -0.38 \\
\hline $\mathrm{W}_{5}$ & 0.01 & 0.02 & 0.03 \\
\hline $\mathrm{W}_{6}$ & 0.39 & 0.29 & 0.35 \\
\hline \multicolumn{5}{|l}{} \\
\hline THE POZNAŃ MODEL & 0.06 & 0.04 & -0.13 \\
\hline $\mathrm{W}_{1}$ & 0.63 & 1.37 & 0.28 \\
\hline $\mathrm{W}_{2}$ & 0.89 & 0.91 & 0.82 \\
\hline $\mathrm{W}_{3}$ & 0.03 & 0.02 & -0.001 \\
\hline $\mathrm{W}_{4}$ & 0.41 & 0.30 & 0.32 \\
\hline GAJDKA AND STOS MODEL & 117.57 & 145.72 \\
\hline $\mathrm{W}_{1}$ & 92.99 & 0.04 & -0.12 \\
\hline $\mathrm{W}_{2}$ & 0.06 & 0.13 & -0.38 \\
\hline $\mathrm{W}_{3}$ & 0.03 & 0.33 & 0.37 \\
\hline $\mathrm{W}_{4}$ & 0.30 & \multicolumn{3}{l}{} \\
\hline
\end{tabular}

Source: self-reported data base on the unitary financial statements of Tauron Polska Energia S.A. as of 31 December 2013, 31 December 2014 and 31 December 2015.

Table 2 presents the values of the indicators of Mączyńska's model, the Poznań model and Gajdka and Stos model for the company PGE S.A over the period of 20132015. Over that time, the company PGE S.A. was classified as a company in a good financial condition by all the models used. 
Table 2. The values of indicators in the selected models for the company PGE S.A. (2013-2015)

\begin{tabular}{|c|c|c|c|}
\hline MĄCZYŃSKA'S MODEL \\
\hline indicators & $\mathbf{2 0 1 3}$ & $\mathbf{2 0 1 4}$ & $\mathbf{2 0 1 5}$ \\
\hline $\mathrm{W}_{1}$ & 1.68 & 1.29 & 0.30 \\
\hline $\mathrm{W}_{2}$ & 22.37 & 8.79 & 6.50 \\
\hline $\mathrm{W}_{3}$ & 0.07 & 0.15 & 0.04 \\
\hline $\mathrm{W}_{4}$ & 0.19 & 0.57 & 0.16 \\
\hline $\mathrm{W}_{5}$ & 0.02 & 0.04 & 0.02 \\
\hline $\mathrm{W}_{6}$ & 0.40 & 0.26 & 0.28 \\
\hline THE POZNAŃ MODEL & 0.07 & 0.15 & 0.02 \\
\hline $\mathrm{W}_{1}$ & 9.39 & 8.06 & 1.97 \\
\hline $\mathrm{W}_{2}$ & 0.99 & 0.99 & 0.95 \\
\hline $\mathrm{W}_{3}$ & 0.09 & 0.07 & 0.08 \\
\hline $\mathrm{W}_{4}$ & \multicolumn{5}{l|}{} \\
\hline GAJDKA AND STOS MODEL & 0.4 & 0.28 & 0.28 \\
\hline $\mathrm{W}_{1}$ & 21.6 & 15.09 & 11.30 \\
\hline $\mathrm{W}_{2}$ & 0.07 & 0.16 & 0.04 \\
\hline $\mathrm{W}_{3}$ & 0.19 & 0.57 & 0.16 \\
\hline $\mathrm{W}_{4}$ & 0.04 & 0.14 & 0.15 \\
\hline $\mathrm{W}_{5}$ &
\end{tabular}

Source: self-reported data base on the unitary financial statements of PGE S.A. as of 31 December 2013, 31 December 2014 and 31 December 2015.

Mączyńska's model classified the company Enea S.A. in 2015 as being at risk of failure. The calculations made for 2013 and 2015 indicated that the company was in a good financial condition. The Gajdka and Stos model as well as the Poznan model defined the company Enea S.A. as a company in a good financial condition over the entire period under study.

Table 4 contains the values of the indicators according to Mączyńska's model, the Poznan model and Gajdka and Stos model for the company IDEON S.A. over the period of 2013-2015. The model by Mączyńska as well as that by Gajdka and Stos classified the company as being at risk of failure in the years 2013-2015. Only the Poznań model was of "different opinion", as its values showed that the company was in a poor financial condition only in 2014, while in 2013 and 2015 the values demonstrated the company's good financial condition. 
Table 3. The values of indicators in the selected models for the company Enea S.A. (2013-2015)

\section{MĄCZYŃSKA'S MODEL}

\begin{tabular}{|c|c|c|c|}
\hline indicators & $\mathbf{2 0 1 3}$ & $\mathbf{2 0 1 4}$ & $\mathbf{2 0 1 5}$ \\
\hline $\mathrm{W}_{1}$ & 0.48 & 0.22 & -0.17 \\
\hline $\mathrm{W}_{2}$ & 7.11 & 4.56 & 2.57 \\
\hline $\mathrm{W}_{3}$ & 0.07 & 0.05 & -0.06 \\
\hline $\mathrm{W}_{4}$ & 0.17 & 0.14 & -0.20 \\
\hline $\mathrm{W}_{5}$ & 0.02 & 0.02 & 0.03 \\
\hline $\mathrm{W}_{6}$ & 0.40 & 0.35 & 0.32 \\
\hline \multicolumn{5}{|l|}{} \\
\hline THE POZNAŃ MODEL \\
\hline $\mathrm{W}_{1}$ & 0.06 & 0.05 & -0.07 \\
\hline $\mathrm{W}_{2}$ & 2.19 & 2.99 & 2.16 \\
\hline $\mathrm{W}_{3}$ & 0.92 & 0.93 & 0.92 \\
\hline $\mathrm{W}_{4}$ & 0.04 & 0.01 & 0.01 \\
\hline GAJDKA AND STOS MODEL & 0.38 & 0.34 \\
\hline $\mathrm{W}_{1}$ & 0.21 & 72.72 & 306.50 \\
\hline $\mathrm{W}_{2}$ & 41.23 & 0.05 & -0.07 \\
\hline $\mathrm{W}_{3}$ & 0.03 & 0.14 & -0.20 \\
\hline $\mathrm{W}_{4}$ & 0.17 & 0.22 & 0.39 \\
\hline $\mathrm{W}_{5}$ & 0.14 &
\end{tabular}

Source: self-reported data base on the unitary financial statements of Enea S.A. as of 31 December 2013, 31 December 2014 and 31 December 2015.

Table 5 presents the values of the indicators of Mączyńska's model, the Poznan model and that by Gajdka and Stos for the company EC "BĘDZIN" S.A. over the period between 2013 and 2015.

The company EC "BĘDZIN" S.A. was assessed as being in a poor financial condition in 2015 by Mączyńska's model and the model by Gajdka and Stos. The values obtained for the other years showed the company as being in a good financial condition. 
Table 4. The values of indicators in the selected models for the company IDEON S.A. (2013-2015)

\begin{tabular}{|c|c|c|c|}
\hline MĄCZYŃSKA'S MODEL \\
\hline indicators & $\mathbf{2 0 1 3}$ & $\mathbf{2 0 1 4}$ & $\mathbf{2 0 1 5}$ \\
\hline $\mathrm{W}_{1}$ & -0.26 & -0.23 & -0.24 \\
\hline $\mathrm{W}_{2}$ & 0.62 & 0.24 & 0.66 \\
\hline $\mathrm{W}_{3}$ & -0.42 & -0.97 & -0.36 \\
\hline $\mathrm{W}_{4}$ & -0.32 & -3.08 & -36.93 \\
\hline $\mathrm{W}_{5}$ & 0.006 & 0,00 & 0.00 \\
\hline $\mathrm{W}_{6}$ & 1.33 & 0.31 & 9.72 \\
\hline THE POZNAŃ MODEL & -0.36 & -1.26 & -0.36 \\
\hline $\mathrm{W}_{1}$ & 1.41 & 0.43 & 0.61 \\
\hline $\mathrm{W}_{2}$ & 0.51 & -0.62 & -0.51 \\
\hline $\mathrm{W}_{3}$ & 0.02 & 0.003 & 0.87 \\
\hline $\mathrm{W}_{4}$ & 1.15 & 0.15 & 0.01 \\
\hline GAJDKA AND STOS MODEL & 321.62 & 290.11 \\
\hline $\mathrm{W}_{1}$ & 252.72 & -0.30 & -0.26 \\
\hline $\mathrm{W}_{2}$ & -0.31 & -3.08 & 0.04 \\
\hline $\mathrm{W}_{3}$ & -0.32 & 4.16 & 1.51 \\
\hline $\mathrm{W}_{4}$ & 1.60 & $\mathrm{~W}$ & 0.3 \\
\hline $\mathrm{W}_{5}$ &
\end{tabular}

Source: self-reported data base on the unitary financial statements of IDEON S.A. as of 31 December 2013, 31 December 2014 and 31 December 2015.

According to Mączyńska' model, in 2013 the company Tauron Polska Energia S.A. was considered to be a company enjoying a very good financial situation, in 2014 it continued to sustain its good condition, however, in 2015 the sales revenues fell substantially (negative value), which had the effect that the company was classified as being at risk of failure. The second of the models analyzed (the Poznan model) assessed the financial condition of the company Tauron S.A. over the years 2013-2015 as very good. The Gajdka and Stos model recognized the company as good in 2013 and 2014, however the year 2015 saw a substantial decrease in the company's net profit, which contributed to assessing the company as at risk of failure. 
Table 5. The values of indicators in the selected models for the company EC "BEDDZIN" S.A. (2013-2015)

\section{MĄCZYŃSKA'S MODEL}

\begin{tabular}{|c|c|c|c|}
\hline indicators & $\mathbf{2 0 1 3}$ & $\mathbf{2 0 1 4}$ & $\mathbf{2 0 1 5}$ \\
\hline $\mathrm{W}_{1}$ & 0.59 & 8.45 & -0.002 \\
\hline $\mathrm{W}_{2}$ & 7.84 & 60.82 & 3.13 \\
\hline $\mathrm{W}_{3}$ & -0.03 & 0.08 & 0.00 \\
\hline $\mathrm{W}_{4}$ & -0.03 & 0.10 & -0.45 \\
\hline $\mathrm{W}_{5}$ & 0.09 & 0.13 & 0.00 \\
\hline $\mathrm{W}_{6}$ & 0.99 & 0.80 & 0.002 \\
\hline THE POZNAŃ MODEL & -0.02 & 0.07 & 1.10 \\
\hline $\mathrm{W}_{1}$ & -0.42 & 7.74 & 14.89 \\
\hline $\mathrm{W}_{2}$ & 0.87 & 0.98 & 1.00 \\
\hline $\mathrm{W}_{3}$ & -0.01 & 0.09 & -1.10 \\
\hline $\mathrm{W}_{4}$ & 0.95 & 0.67 & 0.002 \\
\hline GAJDKA AND STOS MODEL & 54.18 & 0.00 \\
\hline $\mathrm{W}_{1}$ & -0.03 & 0.05 & 0.001 \\
\hline $\mathrm{W}_{2}$ & -0.03 & 0.10 & -0.45 \\
\hline $\mathrm{W}_{3}$ & 0.13 & 0.08 & 0.32 \\
\hline $\mathrm{W}_{4}$ & \multicolumn{2}{|l}{} \\
\hline $\mathrm{W}_{5}$ &
\end{tabular}

Source: self-reported data base on the unitary financial statements of EC "Będzin" S.A. as of 31 December 2013, 31 December 2014 and 31 December 2015.

The assessments and values of the parameters of the selected models as well as the accuracy of the prediction are presented in Tables 6-10.

Table 6. The value and interpretation of discriminatory models for the company Tauron Polska Energia S.A.

\begin{tabular}{|r|r|r|r|r|r|r|}
\cline { 2 - 7 } \multicolumn{1}{c|}{} & \multicolumn{2}{|c|}{ Mączyńska's model } & \multicolumn{2}{|c|}{ The Poznań model } & The Gajdka and Stos model \\
\hline year & value & interpretation & value & interpretation & value & interpretation \\
\hline 2013 & 1.98 & Very good & 6.06 & very good & 0.71 & good \\
\hline 2014 & 1.56 & good & 7.02 & very good & 0.76 & good \\
\hline 2015 & -3.46 & at risk of failure & 2.20 & very good & 0.28 & at risk of failure \\
\hline
\end{tabular}

Source: self-reported data 
Table 7. The value and interpretation of the selected functions for the company PGE S.A.

\begin{tabular}{|rr|r|r|r|r|r|}
\cline { 2 - 7 } \multicolumn{1}{c|}{} & \multicolumn{2}{c|}{ Mączyńska's Model } & \multicolumn{2}{|r|}{ The Poznań model } & \multicolumn{2}{c|}{ The Gajdka and Stos model } \\
\hline year & value & interpretation & value & interpretation & value & interpretation \\
\hline 2013 & 6.06 & very good & 17.65 & very good & 0.92 & good \\
\hline 2014 & 7.02 & very good & 15.66 & very good & 1.20 & very good \\
\hline 2015 & 2.20 & very good & 5.44 & very good & 0.81 & good \\
\hline
\end{tabular}

Source: self-reported data

Table 8. The value and interpretation of discriminatory models for the company Enea S.A.

\begin{tabular}{|r|r|r|r|r|r|r|}
\cline { 2 - 6 } \multicolumn{1}{c|}{} & \multicolumn{2}{|c|}{ Mączyńska's model } & \multicolumn{2}{|c|}{ The Poznań model } & \multicolumn{2}{r|}{$\begin{array}{r}\text { The Gajdka and Stos } \\
\text { model }\end{array}$} \\
\hline year & value & interpretation & value & interpretation & value & interpretation \\
\hline 2013 & 2.89 & very good & 5.54 & very good & 0.84 & good \\
\hline 2014 & 1.98 & good & 6.62 & very good & 0.80 & good \\
\hline 2015 & -1.52 & $\begin{array}{r}\text { at risk of } \\
\text { failure }\end{array}$ & 4.82 & very good & 0.55 & good \\
\hline
\end{tabular}

Source: self-reported data

Table 9. The value and interpretation of discriminatory models for the company IDEON S.A.

\begin{tabular}{|c|c|c|c|c|c|c|}
\hline & \multicolumn{2}{|c|}{ Mączyńska's model } & \multicolumn{2}{|c|}{ The Poznań model } & \multicolumn{2}{|c|}{ The Gajdka and Stos model } \\
\hline year & value & interpretation & value & interpretation & value & interpretation \\
\hline 2013 & -6.00 & risk of failure & 0.88 & good & -0.58 & at risk of failure \\
\hline 2014 & -25.39 & risk of failure & -8.92 & at risk of failure & -3.75 & at risk of failure \\
\hline 2015 & -4.78 & risk of failure & 0.94 & good & -0.17 & at risk of failure \\
\hline
\end{tabular}

Source: self-reported data 
Table 10. The value and interpretation of discriminatory models for the company EC "Będzin" S.A.

\begin{tabular}{|r|r|r|r|r|r|r|}
\cline { 2 - 7 } \multicolumn{1}{c|}{} & \multicolumn{2}{|c|}{ Mączyńska's model } & \multicolumn{2}{c|}{ The Poznań model } & \multicolumn{2}{c|}{ The Gajdka and Stos model } \\
\hline year & value & interpretation & value & interpretation & value & interpretation \\
\hline 2013 & 1.19 & good & 5.06 & good & 0.62 & good \\
\hline 2014 & 18.96 & very good & 14.98 & very good & 0.82 & good \\
\hline 2015 & -2.00 & risk of failure & 22.18 & very good & 0.29 & at risk of failure \\
\hline
\end{tabular}

Source: self-reported data

According to Mączyńska's model, PGE S.A. was considered to be in a very good financial situation in 2013-2015. The Poznań model also classified the company as one in a very good financial situation over the period examined. The Gajdka and Stos model also classified the company as good over the entire period in question.

The analysis of the financial condition of the company Enea S.A. carried out using Mączyńska's model indicated that in 2013 the company was in a very good financial situation, in 2014 it was in a good financial situation, while in 2015, following the losses recorded at the end of the accounting period, it was considered to be at risk of failure. However, the values of the function in the Poznan model indicated that the company was in a very good financial situation over the period in question. The value of the function in the Gajdka and Stos model indicated that over the period of 20132015 the company was in a good financial situation.

According to Mączyńska's model, the company IDEON S.A. was considered to be at risk of failure over the entire period examined. This interpretation was largely affected by the negative gross profit recorded for the years 2013-2015. The Poznan model, on the other hand, assessed the company's financial condition as good in 2013; yet in 2014 when the short-term liabilities exceeded the value of the constant capital, the value of the function was negative, which implied that the company was at risk of failure. However, in 2015 all the indicators analyzed improved with the financial situation becoming good again. Moreover, the Gajdka and Stos model considered the company to be at risk of failure over the entire period examined.

Heat and Power Plant "Będzin" S.A., according to all models was considered to be in a good financial situation over the years 2013-2014. In 2015, however, following the negative gross profit, the level of stocks at zero and no sales, the company was considered to be at risk of failure by Mączyńska's model and the Gajdka and Stos 
model. Only the Poznan model, which does not take into account these elements in its function, considered the company EC "Będzin" as being in a very good financial condition.

The analysis found that the classification of a company in terms of whether or not it is at risk of failure may differ depending on the model applied. Considering the financial situation of the companies: Tauron, PGE, Enea, IDEON and "Będzin", one should emphasize that all the companies are still listed on the Warsaw Stock Exchange. All the models included in the study showed that the financial situation of the companies examined was good over the period of 2013-2015, with the exception of the company IDEON, which according to Mączyńska's model and the Gajdka and Stos model was at risk of failure throughout the entire period examined. Only the Poznan model in the years 2013 and 2015 classified the company as a company in a good financial condition. The Poznań model diverges in its interpretation from the other models. One has to note that this model examines other aspects of financial statements, with gross and net profit being outside its focus, unlike in the case of the majority of indicators applied in Mączyńska's model and the Gajdka and Stos model.

However, the studies conducted demonstrate that while attempting to assess the risk of bankruptcy one should not use only one model, for models may differ as to their interpretation of the company's financial situation.

\section{Conclusions}

On the basis of the studies conducted by the author the following conclusions can be drawn:

- the companies which belong to capital groups of the Polish energy sector are in a much better financial condition that companies without the state shareholding,

- through the calculations conducted, it was possible to indicate one company which was at the greatest risk of failure and that was IDEON S.A. All models showed the lowest values for this company compared to the rest of 
the sample. According to Mączyńska's model and the Gajdka and Stos model, the company was classified as being at risk of failure over the entire period under study.

- discriminatory models of early warning are not sufficiently reliable tools. An adequate choice of a model to assess the risk of failure allows for obtaining a high quality forecast;

- one should not forecast bankruptcy prediction based on just one model. In order to make the analysis results objective, one should apply a few discriminant functions and to observe how their values change over time;

- only estimation samples selected adequately so as to match the characteristics of the object under study allow for obtaining, a long time in advance, high quality forecasts of insolvency;

- the application of discriminatory models in company management makes it possible to extend the period over which a company functions on the market while limiting the risk of making wrong management decision.

The author believes, drawing on the discussion and calculations, that it is not possible to assign a specific model to the entire energy sector, for there have so far been no studies which would match bankruptcy prediction models to particular industries and businesses. The author, however, has observed that Mączyńska's model examines the energy sector in a most detailed way owing to its components. Still, in investigating the risk of failure one should not rely on calculations obtained on the basis of just one model.

\section{References}

Analizy-prognozy finansowe.pl, Niezbędnik analityka, www.analizy-prognozy.pl/analizy-prognozyfinansowe/analiza/dyskryminacyjna [06.10.2016].

Bień W. (1999), Zarządzanie finansami przedsiębiorstwa, Difin, Warszawa, pp. 24-25.

Gajdka J., Stos D. (1996), Wykorzystanie analizy dyskryminacyjnej w ocenie kondycji finansowej przedsiębiorstw, w: Restrukturyzacja w procesie przekształceń i rozwoju przedsiębiorstw, ed. Borowiecki R., AE Kraków, Kraków, pp. 59-63. 


\section{BANKRUPTCY PREDICTION MODELS AS A SOURCE OF ASSESSMENT ...}

Galbarczyk T., Świderska J. (2011), Bank komercyjny w Polsce. Podręcznik akademicki, Difin, Warszawa, pp. 112-115.

Hadasik D. (1998), Upadłość przedsiębiorstw w Polsce i metody jej prognozowania, Zeszyty Naukowe, Seria II: prace habilitacyjne, zeszyt 153, AE Poznań, Poznań.

Hamrol M., Chodakowski J. (2008), Prognozowanie zagrożenia finansowego. Wartość predykcyjna polskich modeli analizy dyskryminacyjnej, „Badania Operacyjne i Decyzyjne”, vol. 3, pp. 17-32.

Kisielińska J., Waszkowski A. (2010), Polskie modele prognozowania bankructwa przedsiębiorstw i ich weryfikacja, ,Zeszyty Naukowe SGGW”, vol. 82.

Mączyńska E., Zawadzki E. (2006), Dyskryminacyjne modele predykcji bankructwa przedsiębiorstw, „Ekonomista”, vol. 2, pp. 216-217.

NBPortal.pl. Portal wiedzy ekonomicznej, www.nbpportal.pl/slownik/pozycjeslownika/kondycjafinansowa [30.11.2016].

Pierścionek Z. (1996), Strategia rozwoju firmy, PWN, Warszawa.

Rogowski W.K. (1999), Możliwości wczesnego rozpoznania symptomów zagrożenia zdolności płatniczej przedsiębiorstwa, „Bank i Kredyt”, vol. 6, pp. 56-72.

Siemińska E. (2002), Metody pomiaru i oceny kondycji przedsiębiorstwa, Dom Organizatora, Toruń.

Siemińska E. (2003), Finansowa kondycja firmy. Metody pomiaru i oceny, Poltext, Warszawa.

Thuczak A. (2013), Zastosowanie dyskryminacyjnych modeli przewidywania bankructwa do oceny ryzyka upadłości przedsiębiorstw, „Zeszyty Naukowe Wyższej Szkoły Bankowej we Wrocławiu”, vol. 2 (34), pp. 423-434.

Ustawa z dnia 01 października 2004 r. Wytyczne wspólnotowe dotyczące pomocy państwa w celu ratowania i restrukturyzacji zagrożeń, Dziennik Urzędowy Unii Europejskiej 244.

Ustawa z dnia 10 kwietnia 1997 r. Prawo energetyczne, Dziennik Urzędowy, Nr 54, poz. 348.

Ustawa z dnia 4 lutego 1994 r. Prawo geologiczne i górnicze, Dziennik Urzędowy, Nr 27, poz. 96.

Walczak M. (2007), Analiza finansowa w zarządzaniu współczesnym przedsiębiorstwem, Difin, Warszawa, s. 54-69. 